Florida International University FIU Digital Commons

\title{
Proceduralizing Privilege: Designing Shakespeare in Virtual Reality and the Problem with the Canon
}

David M. Frisch

Florida International University, dfris005@fiu.edu

DOI: $10.25148 /$ etd.FIDC000231

Follow this and additional works at: https://digitalcommons.fiu.edu/etd

Part of the Continental Philosophy Commons, Literature in English, British Isles Commons, Other Classics Commons, and the Race, Ethnicity and Post-Colonial Studies Commons

\section{Recommended Citation}

Frisch, David M., "Proceduralizing Privilege: Designing Shakespeare in Virtual Reality and the Problem with the Canon" (2016). FIU Electronic Theses and Dissertations. 2491.

https://digitalcommons.fiu.edu/etd/2491 


\title{
FLORIDA INTERNATIONAL UNIVERSITY
}

Miami, Florida

\section{PROCEDURALIZING PRIVILEGE: DESIGNING SHAKESPEARE IN VIRTUAL REALITY AND THE PROBLEM WITH THE CANON}

\author{
A thesis submitted in partial fulfillment of \\ the requirements for the degree of \\ MASTER OF ARTS \\ in \\ ENGLISH \\ by \\ David Frisch
}


To: Dean Michael R. Heithaus

College of Arts, Sciences and Education

This thesis, written by David Frisch, and entitled Proceduralizing Privilege: Designing Shakespeare in Virtual Reality and the Problem with the Canon, having been approved in respect to style and intellectual content, is referred to you for judgment.

We have read this thesis and recommend that it be approved.

$\begin{array}{r}\hline \text { Heather Blatt } \\ \hline \text { Andrew Strycharski } \\ \hline \text { James Sutton, Major Professor }\end{array}$

Date of Defense: March 25, 2016

The thesis of David Frisch is approved.

Dean Michael R. Heithaus
College of Arts, Sciences and Education

College of Arts, Sciences and Education

Florida International University, 2016 
ABSTRACT OF THE THESIS

PROCEDURALIZING PRIVILEGE: DESIGNING SHAKESPEARE IN VIRTUAL REALITY AND THE PROBLEM WITH THE CANON

\author{
by \\ David Frisch \\ Florida International University, 2016 \\ Miami, Florida \\ Professor James Sutton, Major Professor
}

This thesis focuses on the development of the first project for FIU's ICAVE, The Globe Experience, presented as part of the "First Folio! The Book That Gave Us Shakespeare” exhibit during February, 2016. The thesis is divided into two parts. The first part is the project itself: a virtual reality recreation of going to The Globe Theater to see a play by William Shakespeare. The second part examines the digital project and outlines how Walter Benjamin and postcolonial theorists influenced the design of The Globe Experience, resulting in, what I call, a "temporally and spatially disjointed London.” From this examination, the thesis goes on to question the role of canonical literature in the humanities. I go on to make the argument that the design decisions made in recreating The Globe reveals the ways in which canonical literature can reinforce and support hierarchical ideologies which can impede student learning. 


\section{TABLE OF CONTENTS}

$\begin{array}{ll}\text { CHAPTER PAGE } & \text { PAT }\end{array}$

Proceduralizing Privilege: Designing Shakespeare in Virtual Reality and the Problem

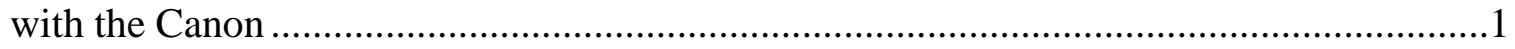

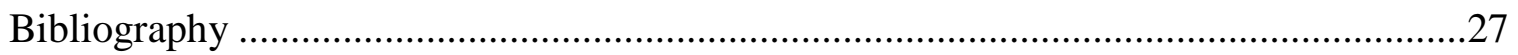


Proceduralizing Privilege: Designing Shakespeare in Virtual Reality and the Problem with the Canon

Within the humanities, we practice critical thinking, analysis, and creative thought. We examine literature, culture, society, and the other arts in order to gain perspective on what it means to be exist in the world. In the growing field of Digital Humanities, efforts have been made to use new and innovative technologies to find new meanings, and inspire methods of analysis, from classic works of art. But what about the creation of works and experiences? As researchers and academics, we are dependent on the creations of others in order to analyze and gain insight. We need authors to write the books for us to read; directors to create the films we watch; and other people to create so we can examine. We are dependent on these people. So why not take the creative role ourselves?

These were the questions I asked myself as I began work on Florida International University's First Folio: The Globe Theater Experience ${ }^{1}$. In theory, the project was to be a virtual reality recreation of what it might have been like to see a play at The Globe Theater. It would be exhibited alongside the First Folio as part of the Folger Shakespeare Library’s national tour in 2016, open at FIU during the month of February, and presented to students from the Miami-Dade County Public Schools (MDCPS). In practice,

\footnotetext{
${ }^{1}$ As a graduate student in FIU's English department, my studies were primarily focused in postcolonial theory and videogame studies. I was particularly interested in the relationship between the player and the game and the processes in which meaning is both reinforced and deferred through the story and gameplay elements. Considering this interest, my chair approached me to lead a team of students from FIU's School of Architecture, as well as the College of Computer Science and Information Sciences, to come up with a digital recreation of The Globe Theater.
} 
considering that the student population in MDCPS, my anticipated audience, is $68.4 \%$ Hispanic, and 22.3\% Black Non-Hispanic (MDCPS 2), as well as my own studies in postcolonial theory and literature, I wanted to create a representation that focused on the sociological makeup of Early Modern London. Considering the central placement of Shakespeare within the traditional white-patriarchal canon, I felt it was important to include diverse representation within the VR experience. Surprisingly, I found that not only was it materially difficult to include these representations, but the experience also proceduralized how the canon continues to marginalize communities and protect hierarchal ideologies. The project aimed to remove Shakespeare from the rhetoric of his timelessness, and demonstrate that Shakespeare is not quite timeless at all. Despite this goal, the project inevitably re-ascribed canonical thinking and the white, male privileged perspective by virtue of its canonical content —an uneasy dialogue, the results of which I am not wholly satisfied with.

In this paper, I outline the way in which my team and I created a virtual reality experience of Shakespeare's Globe Theater. Focusing heavily on the theoretical underpinnings of the project, I will show how I originally thought about the project, and then how the process of creating the past led to a questioning of Shakespeare's place in today’s changing world.

\section{THE TECHNOLOGY}

The CAVE, shorthand for Computer Augmented Virtual Environment, is a small room which creates a 3D virtual reality environment that participants can interact with and immerse themselves in. Developed and customized by the Mechdyne Corporation, the 
ICAVE (Integrated-CAVE) installed at Florida International University, is a hexagonal display system, with five screens and projectors for each side (see Figure 1). Participant movement is followed by small motion trackers on the eyeglasses and controller in tandem with the motion tracking software trackd ${ }^{\mathrm{TM}}$.

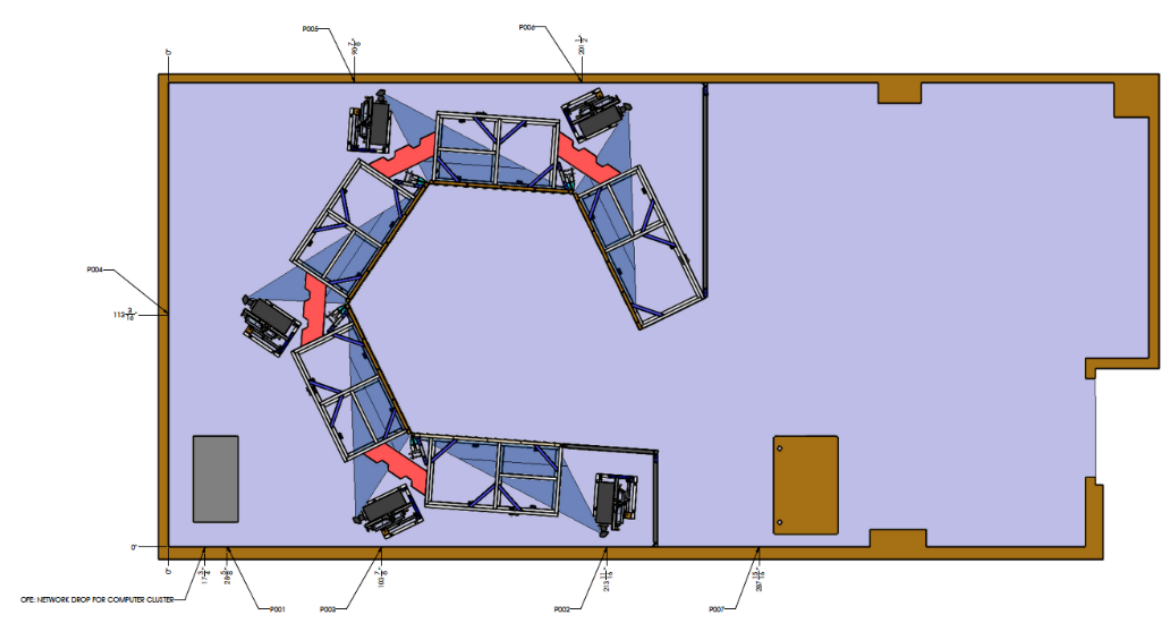

Figure 1

Four people can wear the eyeglasses at a time, with one driver set and three passenger sets. The driver holds the controller and is the only participant tracked by the motion sensors. The three passengers experience the ICAVE in 3D, but projectors are programmed to respond only to the driver. Simulations and environments made for the ICAVE are developed using Unity, a popular game engine used mainly by small game developers. A Unity program must be developed in tandem with the Mechdyne plugin, getReal3d, in order to run on the ICAVE. The plugin is what allows for the integration of tracking technology and the engine. The technology has traditionally been used in research and data computation, as seen in advertisements on the website that boast the ICAVE's ability to “Analyze and interpret spatially-related data faster,” "Intuitively navigate realistic, life-size environments for research or design," and "Focus on your 
data, not the technology, with a fully integrated display, software, computing, and support solution” (Mechdyne). It has been used by architecture students for urban planning and modeling, as well as medical schools who use it to show full scale body functions.

Lacking from the advertising of the ICAVE, as well as its intended uses, have been the discussion of how the humanities can grow from the application of this new technology. The ICAVE is not widely used in the humanities. The University of Illinois in Chicago used other CAVE technology to recreate the Minotaur's labyrinth from Greek mythology. Allegorically they hoped to recreate the journey of Theseus and Dante Alighieri. The University of Wyoming used the technology to create a Fine Arts exhibition in which participants could see, and interact with, rare works of art that participants would not normally have access to. In addition, a handful of individual artists have used CAVEs to explore the creative potential of virtual reality, but in the eyes of the institutions that buy them, CAVEs are meant for the hard sciences. The First Folio: The Globe Experience breaks away from this trend by not only presenting a digital interactive narrative set in Early Modern London, but also presented it alongside an exhibition of the First Folio sponsored by the Folger Shakespeare Library. In this way, FIU students, as well as the general public, have access to visit the exhibition of Shakespeare's First Folio alongside a digital recreation of what it might have been like to visit the Globe Theater.

\section{THE EXPERIENCE}

By presenting The Globe Experience alongside the exhibition of the First Folio, the goal was to create an innovative new approach to expose Shakespeare to a new generation of 
students. By making the ICAVE a digital and multi-modal experience, my team and I could appeal to what Katherine Hayles describes as the hyper-attentiveness of students ${ }^{2}$. Participants would typically see the First Folio and, when they arrive, be greeted by the tagline "You've seen the book where the plays came from, now experience where they were performed". When students and visitors would come to the ICAVE, they would take on the role of a Spaniard visiting the Globe Theater to see Shakespeare's Henry V.

The simulation begins with a first person view of the Spaniard looking across the Thames at Old St. Paul's Cathedral. It is a foggy day, and the city across the river is not quite clear, only the dim outline of London can be seen. The participants can hear the steady ring of church bells signaling the hour. Behind the participant, the hectic crowds of Bankside can be heard above the birds and wind. A man sleeps on a boat in front of them. When they turn around, they see a white Spaniard with fanciful dress flanked by two children.

When the participant approaches the man, he begins talking in Spanish. The character makes jokes about the Thames River, as well as comparing Shakespeare to the Spanish playwrights of the time. All the while, the children around him are asking him what he is saying and he promptly translates for them. The conversation is in Early Modern Spanish, with English subtitles below the characters. Once the conversation ends, the participant is free to explore the section of Bankside that was recreated.

Populating the area are Londoners in the streets, selling goods and chasing rats, among a number of other activities. Notable of the Londoners, in this recreation, is that

\footnotetext{
${ }^{2}$ Katherine Hayles describes hyper-attention as "characterized by switching focus rapidly among different tasks, preferring multiple information streams, seeking a high level of stimulation, and have a low tolerance for boredom" (187).
} 
they are 2D characters (figure 2). The source of these characters, which were given joints and animated, are the works of Pieter Brueghel the Elder, the Younger, and Hans Holbein. Walking through the 3D city, passing 2D characters, the participant can visit two locations: a pub and a brothel. With each movement down the central road, or across it, the outline of The Globe looms in the distance.

Within Bankside, there are multiple interactions that the participant can trigger. They can speak to the brothel mistress, a pub owner, and a vagrant, amongst a host of other characters. At the center of each interaction are choices set around issues of currency. Will the player give the non-player character an English coin or a Spanish one? Choosing between these two leads to different responses from the characters.

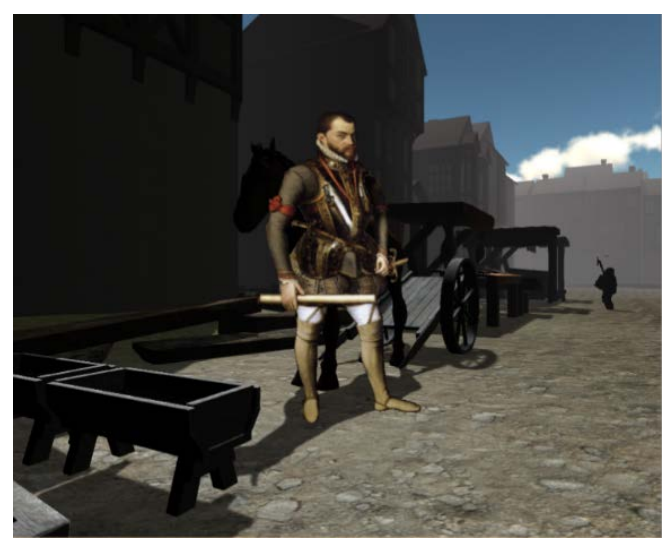

Figure 2

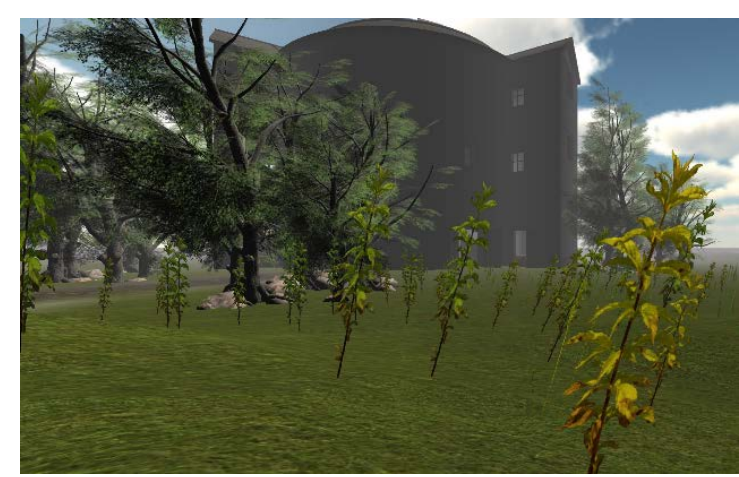

Figure 3

While the participant is exploring, the other Spaniard has moved across town and has begun waving them over to him. As the participant moves towards the Spaniard, he reminds them—in Spanish—that Henry $V$ is starting soon and they must hurry. Once the participant chooses to move this way, they begin on the path towards The Globe. A fog covers the area and the participant can see the outline of the theater in the distance (figure 3). As they approach the theater, a man at the door asks for payment, and the participant 
makes their way inside. Situated in "the pit," the area right in front of the stage, with the "groundlings,” the participant is surrounded by the loud and hectic crowds of London playgoers. Once a trigger point is walked over, an animated character walks out on stage and begins the opening monologue to Henry $V$. As the monologue ends, the screen fades to black and the Globe Experience ends.

\section{THE INITIAL THEORY}

The driving vision in creating The Globe Experience was to create a subversive and sociological recreation of Early Modern London. Considering Shakespeare as one of the most prolific canonical writers, my goal was to situate his theater in a place that would include a wide variety of representation and reparation ${ }^{3}$. To accomplish my goal, I had to create a space that was not historically accurate in the general sense of the term. When considering historical space in terms of Shakespeare, there is an imperative to interrogate the idea of accuracy in terms of history because of Shakespeare's placement as a canonical writer.

I am critical of a history that is presented as objective and waiting to be uncovered by the historian. Michel-Rolph Trouillot characterized this objective conception of history as a viewpoint in which "power is unproblematic, irrelevant to the constructions of the narrative as such” (5). He then explains a spatial conception of history, always in relation to the present, stating:

\footnotetext{
${ }^{3}$ I use the word reparations in the sense of a cultural reparation. Since the damage done to these marginalized communities has been done on both a fiscal and cultural level, I believe there is an imperative to responsibility address these groups in creative work that deals with the past.
} 
Both its popular and scholarly versions assume the independent existence of a fixed past and posit memory as the retrieval of that content. But the past is only past because there is a present, just as I can point to something over there only because I am here. But nothing is inherently over there or here. In that sense, the past has no content. The past—or, more accurately, pastness, is a position. Thus in no way can we identify the past as past (15).

In this conception of history, to tell the past is to create the past, since history will always be a narrative. Within this framework, the material artifacts of the archive, used to create the narrative, have power only insomuch as they are classified in terms of importance and relevance by the keepers of the archive. These keepers, as Derrida discusses in his work Archive Fever, "have the power to interpret the archives. Entrusted to such archons, these documents in effect speak the law: they recall the law and call on or impose the law" (2). The law, explained here, is the indisputable force of history as told by the history books and the historians that write them. What lay in the archive lay in their power, and on the basis of the history that they have created, they create more history and impose that history upon future history. Or as Derrida puts it:

By consignation, we do not only mean...the act of assigning residence...but here the act of consigning through gathering together signs. It is not only the traditional consignatio, that is, written proof, but what all the consignatio begins by presupposing. Consignation aims to coordinate a single corpus, in a system of synchrony in which all the elements articulate the unity of an ideal configuration (3). 
Explicated here is the way unity and logic is assigned to both the archive and history in the creation of an ideal, and popular conceptions of history are nothing more than narratives told by those in power. The issue with the archive, Derrida says, is that it creates a specific historical narrative which necessarily excludes those who are not deemed worthy of the archive. It is for this reason that, while I extensively researched Early Modern London, I used the narratives as points of inspiration to create something new.

I also wanted to create a space outside of linear time and create a temporally disrupted Bankside. In doing so, I hoped to gesture towards a postcolonial conception of time and narrative. Heather Russell, in her book Legba's Crossing: Narratology in the African Atlantic, states that "Narrative representation itself in its attempt to fix time within a traditionally 'real' or 'imaginary' construct—or what we familiarly call "textual representation”—cannot occur in a linear, teleological, or preordained fashion” (15). The problem with linear representations and conceptions of time lie in the destructive myth of progress.

In Walter Benjamin’s “Theses on the Philosophy of History,” he asserts that conceptions of progress do "not adhere to reality but [make] dogmatic claims" (260). Criticized here is the common idea that the present is better than the past. We see these dogmatic claims manifested in reference to societal structures, technological and medical innovations, and even our conceptions of reality. Benjamin goes on to reveal that all these ideas of progress are tied to "the progress of mankind itself" (260). Progress thus becomes a tool to create and reinforce hierarchal notions of humanity, in which there is an unwanted time, condition, or group of people that must be overcome and surpassed to 
create an infinitely better future. We can see this in Georg Hegel's infamous statement from his Philosophy of History that black “consciousness has not yet attained to the realization of any substantial objective existence-as for example, God, or Law-in which the interest of man's volition is involved and in which he realizes his own being;” followed by the assertion that "we leave Africa, not to mention it again. For it is no historical part of the World; it has no movement or development to exhibit” (99). Seen here is the way in which one group of people continues to be marginalized because they are seen as behind or having made no progress. The implications of this are abundant as we can consistently point out how black communities have been marginalized and oppressed.

Benjamin then asserts that the "concept of the historical progress of mankind cannot be sundered from the concept of its progression through a homogenous empty time” (261). Homogenous time represents the empty time of the past as it is perceived by the traditional historian and researcher. History, in this viewing, portrays time as a linear progression of events that lead to the next event, which lead to the next event. Time is not seen on a 1:1 basis in which one cause has one effect, but rather it is regarded as a multitude of events that cause one result in a forward moving fashion. This particular conception of time allows one moment to cause an infinite amount of outcomes, but there is only one which follows on a linear path. So for the researcher, if a situation can cause any event, that means that there are events in which we cannot know the significance of something until the historian uncovers it, filling the empty time of the past. For Benjamin, history cannot be regarded so monolithically; rather, past, present, and future all exist at the same time, in a giant abridgement, as a constellation of the current era with 
a "definite earlier one” (263). One moment does not cause infinity, but rather infinity causes infinity unto itself as we create history out the ashes of the forgotten. Here, we have a conception of time in which our relationship to a past, present, and future becomes related in the creation of a narrative that can empower. Jean-Luc Nancy argues that "invention is always without model and without warranty. But indeed that implies facing up to turmoil, anxiety, even disarray. Where certainties come apart, there too gather the strength that no certainty can match” (158). With the loss of certainty in the historical past, I hoped to create some model that students could relate to outside of the constraining curriculum which is usually prescribed to them.

It was with these ideals in mind that I chose to create this temporally and spatially disjointed Bankside. The Globe Experience holds a Bankside which, by encompassing a space and time of 40 years (1580-1620) is both fantastical and imaginary, but also accurate in terms of its material reality. This fantastical representation is most evident with the inclusion of Holland's Leaguer and the choice of characters in which the participants interact. Holland's Leaguer was a brothel south of the Thames river, but not in the immediate vicinity of The Globe, as in my representation. My choice to include the famous brothel was because of its history as a space of female resistance. The brothel was owned and run solely by women and catered to those who had the wealth. When King James VI came into power, he ordered the brothel closed, but the women of the building refused to follow his orders. When he sent soldiers to forcibly remove them, they filled their chamber pots with boiling water and successfully fought off the King's men (Dittmore). Including Holland's Leaguer in Bankside creates a historical space not bound by linear time. It actively resists the threat of erasure and supports a narrative of women 
in history outside the belief that in the past women were more passive than they are now. As Benjamin writes, "For every image of the past that is not recognized by the present as one of its own concerns threatens to disappear irretrievably” (255).

To reinforce these ideas, the characters chosen for the story come from artists working from 1580-1620. The citizens of The Globe Experience are both temporally and spatially displaced, as they have been taken from works of art that range forty years, as well as come from different countries. The three artists that my team and I utilized were Dutch painters who painted multiple scenes of the English gentry. Using these artists, a history of the English is generated from the gaze of the foreigner. Using these artists subverts the traditional telling of the history of a country by the countrymen. Unfortunately, their status as white-privileged European artists still limits their representation. Their status is easily seen in the lack of diversity within the scenes. To create a space outside of traditional history, it was necessary to go outside the traditional archives.

The archival movement outwards is most apparent in the representation of black and African characters in the ICAVE. The availability of portraits of people of color is dismal enough that just including diversity in the representation took some research. The 
Barmaid in the simulation is from a work by Abraham Janssens called "The Agrippine

Sibyl” circa 1575 (figure 4).

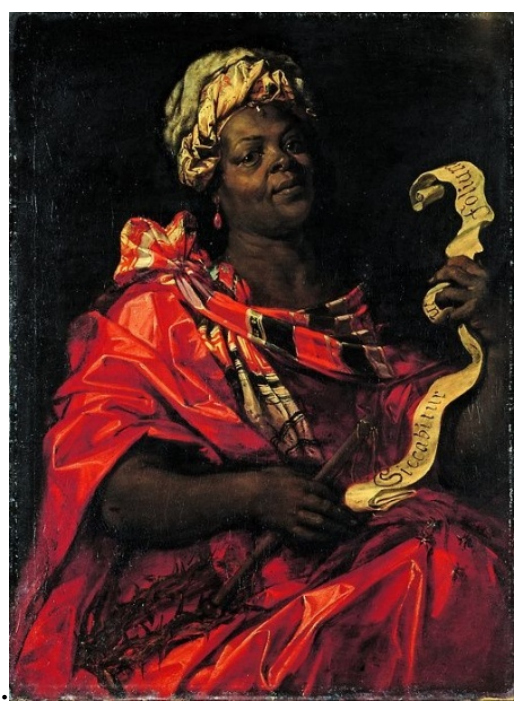

\section{Figure 4}

Considering the author and the date of the portrait, the purpose for her inclusion was to augment a sociological deficit rather than adhere to a misguided sense of historical accuracy ${ }^{4}$. Common in popular recreations of the past is the erasure of people of color, and the erasure creates a situation in which large groups of people are seen as separate from history, and thus not worthy of history. At stake in an erased recreation is the representation of marginalized groups. Fiction and representations of the past have a direct impact on the way we conceptualize the present. Abdul R. JanMohamed argues that "the relation between imperial ideology and fiction is not unidirectional: the ideology does not simply determine the fiction. Rather, through a process of symbiosis, the fiction

\footnotetext{
${ }^{4}$ In fact, the only piece of the recreation which does adhere to the idea of historical accuracy is the architecture. The impetus for this once more lies in the idea of representation. The architecture of Early Modern London is one that fills the archives. It is prevalent in every history book and acts as a marker for the time period. While I resist the notion of recreating a fixed point in a linear time, the materiality of Early Modern London is not in question.
} 
forms the ideology by articulating and justifying the position and aims of the colonialist” (5-6). In a recreation of the past-be it in a movie, painting, book, or digital narrativean imperative to responsibly (re)present is unavoidable. To proliferate the absence of people of color in recreating the past, because they have been erased from history, further alienates and marginalizes communities. Heather Russell argues that "if you no longer have to rely upon a linear and fixed construction of "the story of your people" but can imaginatively draw upon past, present, future, dead, alive, and yet-to-be-born to create that self-same story, what opens up is a radically empowering space in which to define” (15). By creating the space of Bankside as a space divorced from a linear point in time, there exists a freedom to create to empower.

Further, an imperative exists to consider the physical and cultural space where digital interactive narratives are presented or experienced. As an exhibit at FIU, with tours being given to students from MDCPS, the ICAVE was seen by a largely Hispanic and African-American community. It became necessary to include proper representation in the experience in order to make Shakespeare meaningful to these students. It is because of this that the first words heard during the experience are in Spanish, and black characters are seen throughout the recreation. It is important to note that the participant takes on the role of the Spanish Merchant when they see The Globe Experience. The roleplaying, and the encounters with characters aimed to represent a diverse audience, take on importance when one considers the virtual reality experience as an embodied experience. Randal Walser, a computer scientist, argues that digital media, because of its interactive nature, has the ability not only to impart knowledge, but to have its users take that art in as part of their reality. Anna Everett goes further and says we need to pay 
attention to "how video and computer games, like other forms of popular entertainment, might be considered in relation to issues of identity politics, reproduction of racist ideologies, and hegemonies" (146). What Everett and Walser allude to here is "the way videogames mount arguments and influence players” (Bogost viii). This ability to mount an argument in an embodied fashion makes the interactive digital narrative a powerful tool for either subverting or reinforcing ideologies and institutions.

Missing from Everett, Walser's, and Bogost's argument is the way in which the physical space of the digital affects its reception and understanding. In Mark B. Hansen's Bodies in Code, he describes how early conceptions of virtual reality were seen as a “disembodied hyperspace free of all material constraints” (4). These descriptions were highly problematic for the way they erased the materiality of the body from the experience of virtual reality. Instead, he proposes that we consider virtual reality as another aspect of our material reality, and that together they expose a mixed reality paradigm:

rather than conceiving the virtual as a total technical simulacrum and as the opening of a fully immersive, self-contained fantasy world, the mixed reality paradigm treats it as simply one more realm among others that can be accessed through embodied perception or enaction...in this way, emphasis falls less on the content of the virtual than on the means of access to it, less on what is perceived in the world than on how it comes to be perceived in the first place...the new mixed reality paradigm foregrounds the constitutive or ontological role of the body in giving birth to the world (5). 
The active ontological role of the participant is an important distinction to make when considering the ICAVE as the means of access to this experience. The body of the participant stands in the ICAVE with their field of vision encompassed by the screens. While arguments have been made that technologies like the Occulus Rift and other headgear may be a better option for VR, the ICAVE leaves space for the importance of the body and the space in which it is located. By including the entire body as part of the experience, and not just the head, a dynamic relationship can be built between the VR recreation and the space/time of the here and now. These relationships are not all that is at play with VR, however. The issue with this definition of a mixed reality is that is privileges the medium over the content. When considering the ways in which art and representation have an effect on the way we exist in the world, the content of the experience becomes of utmost importance, and developers must keep a goal in mind. The goal-driven design is echoed in readings of Benjamin, who seems to suggest that "traditional art is dead and gone and must now be replaced by a technological art geared to revolutionary purposes" (Kearny 165). While the small pieces of representation in this embodied experience are certainly not revolutionary in an awesome sense, the representations of marginalized persons and the participant's placement in a role of a foreigner work to undermine a traditional narrative of English dominance. With its placement in Miami, Florida — a city of exiles—it is necessary to create a space in which forgotten voices and faces can be interacted with in order to reinforce a space of inclusion and openness to the other. 


\section{REMOVING THE RHETORIC OF TIMELESSNESS}

Visitors to the ICAVE will probably notice one thing in particular: the plague rats

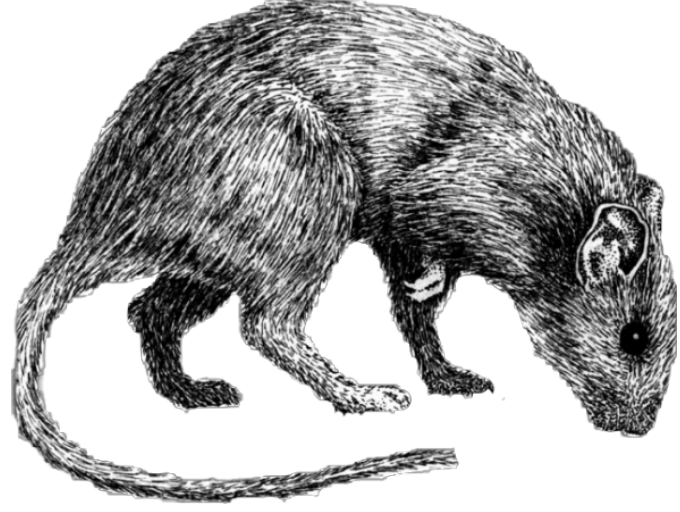

Plague Rat

(above). The tiny disease carrying rodents are seen throughout the experience. It began as a small joke: the rats were carrying the plague at huge rates in Early Modern London, so why not feature some? But as I started getting feedback from some student visitors and faculty, I realized that people were enamored by them. In an article about the exhibit, journalist Sammy Mack writes “On a recent Wednesday morning, a handful of 10th grade English students from Somerset Academy donned 3-D glasses and stepped into Elizabethan London. Their tour guide warned them to watch out for rats carrying plague.” These rats feature in the second sentence of an article introducing a wide readership to the ICAVE. People seemed not to care about the opening monologue from Henry $V$, with its themes of imagination and creativity that were so analogous to the ICAVE experience, or the space of Bankside with its Early Modern architecture. No, it was the rats. But why? 
The beginnings of an answer can be formulated by an examination of the literary canon. In her essay, "Dancing through the Minefield,” literary critic Annette Kolodny describes how "the fact of canonization puts any work beyond questions of establishing its merit and, instead, invited students to offer increasingly more ingenious reading and interpretations, the purpose of which is to validate the greatness already imputed by canonization” (503-504). Relevant for our purposes in this quotation are the ideas of merit and circular reasoning. The canonized work does not need to prove itself. Its greatness has been established by years of scholarly work and the circular logic of student innovation. Student diversity and cultural differences do not matter in the face of universal values and timelessness. The traditional sense of timelessness and the strength of the canon rests upon an ideology similar to the problematic conceptions of history. Kolodny claims that "the reigning critical ideology believes that new literary forms result in some kind of internal dialectic within preexisting styles and traditions” (505). In this way, the history of our literary canon is very much like the homogenous empty time that Benjamin criticizes. Instead of the historian filling in the empty gaps of history which will explain how one moment in time leads to another, we have literary historians who trace the development of styles, searching for missing links and canonizing works to fit a preexisting pattern. She builds on this criticism by asserting: since the grounds upon which we assign aesthetic value to texts are never infallible, unchanging, or universal, we must examine not only our aesthetics but, as well, the inherent biases and assumptions informing the critical methods which (in part) shape our aesthetic responses (508). 
The kind of critical self-reflection that goes along with examining these inherent biases is typically of a complex and deep-seated nature. However, because of the interdisciplinary nature of The Globe Experience, by recreating Early Modern London and the Globe Theater in a digital space, design choices needed to be made that would affect the entire experience. These choices are proceduralized and reveal the biases that uphold a hegemonic canon.

One of the first major design choices made in the experience of the narrative was the casting of the participant in the role of a Spaniard. In the late 1500s, early 1600s, English relations with Spain were volatile at best. A rash of anti-Spaniard plays and leaflets could be found throughout London and the surrounding areas. By making the participant play as a Spaniard, they are forced to take on the role of the foreigner. The role affects the various interactive moments, allowing for an examination of otherness in Early Modern London. Even considering this otherness, the driving factor behind the choice was the privilege of the Spaniard to move through the area.

In the early stages of the project, I had to consider what point of view the participant would be taking. If the participants were going to move through the recreation of Early Modern London, they had to move through it as someone; if not, then any hopes of examining the sociological factors of the time would fall short. Even with this goal, I had to keep in mind that my work was being presented within a larger context, and that the point of the project was to recreate the experience of going to The Globe. The initial goal was the first moment in which the privilege and whiteness of the canon was established. The goal of the project was to recreate the experience of going to The Globe in order to explore a theater going experiencing that has been lost. One design option was 
to put the player in the point of view of a woman at the time, but as Andrew Gurr explains, women at the time were either escorted by men, were prostitutes, or were perceived as prostitutes (102). With a three month timeframe in which to build this, programming a male character to follow the participant would have taken time my team and I did not have. Making the participant a prostitute would have required gameplay elements outside of just seeing a play if I was trying for accuracy. I thought I could make the character an African, but considering the fact that Africans in London at the time were typically slaves, the experience of going to The Globe would have turned into a slave narrative. While making that kind of recreation would have been more in line with my academic interests, it would have shifted the thematic focus of the experience away from The Globe. What this all showed was that the only experience possible in which the participant could move from the edge of The Thames to the pit of The Globe without issue was as a white male character. In creating an experience of going to The Globe, the inherent project is revealed to be to recreate the white-patriarchal experience of going to The Globe. The most I could ameliorate this experience while still exploring some notion of otherness was by making the character a Spaniard. While England and Spain were at odds with each other, Spain was still a world power at the time. The merchant—as a white Spaniard — had the privilege to be mobile even within a community that was prejudiced against him ${ }^{5}$. What this immediately reveals is that once we remove

\footnotetext{
${ }^{5}$ Of note here is the way in which this also elucidates particular reasons for the continuation of the white heteronormative patriarchal narrative: it is easier to produce. Faced with constraints of time and funding, there was no option but to choose a narrative that did not have to engage with any issues of society and allowed for optimal movement through a space. In terms of narrative production, choosing to present a mainstream narrative becomes the equivalent of easy mode on a videogame.
} 
Shakespeare from the rhetoric of universality and timelessness that surrounds him, and place him in a digital space, the rhetoric begins to fall short and deconstruct itself. The same could be said for the rhetoric of timelessness that surrounds the canon and its continued proliferation.

Four common arguments surrounding the purpose of the canon are that (1) the works presented are windows into the past; (2) they showcase longstanding features of the human experience; (3) they have proven themselves academically by their ability to be constantly reinterpreted; and (4) the cultural capital that the canon holds is what is keeping the humanities funded and alive in academia. The problems with most of these arguments have already been established with this paper's criticism of history and the canon. If Shakespeare's plays showcase a window into the past, not only is it the traditionally historical past of those in power, but it is also a past that is continuously reconstructed with each reading and thus only exists as an idea in relation to the present. If the plays are showing the perennial features of the human experience, then whose experience is at the core? The process of the ICAVE suggests that they are certainly not the values of the women of the time or the Africans in London, but rather the audience who was making up the audience of The Globe at the time. Additionally, the argument for the canonical work that is so masterfully created that it can be reinterpreted across time and space has already been put to question and exposed as circular by Kolodny.

So what then of the cultural capital of Shakespeare and the canon? The humanities have certainly declined in prominence as STEM studies have taken center stage in academia. In an interview for the New York Times, one professor reflected on the 22\% drop of English majors in his department saying “in the end, we can’t lose...we 
have William Shakespeare” (Klinkenborg). Yet despite having Shakespeare and the canon, interest in the humanities has steadily been falling. The American Academy of Arts and Sciences found that "The number of bachelor's degrees conferred in the "core" humanities disciplines (English language and literature, history, languages and literatures other than English, linguistics, classical studies, and philosophy) fell 2.4\% from 2012 to 2013, marking the third decline in four years.” I would argue that one reason for this decline is the continuing persistence of the canon.

When considering the success of underrepresented students, it can be useful to look at areas of study outside the humanities as well. In an examination of underrepresentation in STEM disciplines, Stanford researchers learned:

The way students and scientists feel about being a part of the community matters. It is not enough to have students become a part of a science program; they must also be aligned with the norms of the community. This does not mean changing the students, rather it means creating an environment that is welcoming to students from multiple cultural backgrounds..."Having a critical mass of people who are of a similar culture as students removes any potential mystery associated with how students' culture is valued by the institution” (Brown et al. 173).

The issue with the canon in the humanities is that it reinforces the idea that the institution does not value the distinct cultural backgrounds of its changing student body. If the environment and people surrounding a diverse student body can affect student success in a collection of subject areas as ostensibly objective as STEM, then what potential mystery is at play in the humanities where the driving mission is to explore questions of 
being human? If we aim instead to teach other works that are not traditionally part of the canon, I would argue that we can reinvigorate the humanities much in the same way that STEM hopes to increase the number of underrepresented students. The common goal here is to dispel the myth of white superiority.

\section{WHAT IS TO BE DONE?}

As previously noted above, locating artwork that would allow for a diverse representation of Bankside was a project in and of itself. The task of making this space relatable and useful for the Miami student population is also just another variation on a theme of making Shakespeare relatable and teachable for diverse students. As the constant innovations in Shakespearean readings go, academia has seen the development of queer Shakespeare, postcolonial Shakespeare, and even ecocritical Shakespeare. But at what cost? Ania Loomba, in her introductory text to colonialism and postcolonialism, examines the way in which Shakespeare "was used in South Africa to contest as well as foster racism” (81). Inside and outside of educational institutions, leaders used Shakespeare to secure or break down ideologies. In popular cases of the latter, authors have appropriated Shakespeare for their own purposes. Toni Morrison (re)envisions Othello in her performance piece Desdemona, and Aimé Césaire famously rewrote The Tempest from a Caribbean perspective. The issue here is that "the effort to appropriate Shakespeare will only retard the move towards a fresh, more meaningful curriculum” (Loomba 81). The problem with appropriating Shakespeare, to make it more relatable, is echoed by poet Audre Lorde who criticizes scholars who argue “'I can’t possibly teach Black women's writing —-their experience is so different from mine.' Yet how many 
years have you spent teaching Plato and Shakespeare and Proust” (44). The issue is not that Shakespeare and the canon should not be taught, but that they bar the doors of inclusion and representation of marginalized voices and effect the creation of a more inclusive curriculum.

A brief overview of the discourse around curriculum suggests that there is still a divide between educators who seem to think Shakespeare is necessary to teach, and those who understand the problematics and attempt to address them. Alistair Martin-Smith, in his article “Emancipating Shakespeare,” asserts that “we find that many young people perceive Shakespeare’s plays as irrelevant to their lives and concerns. They often experience ‘doing Shakespeare’ as the imposition of an alien (white, middle-class, adult) cultural form” (150). Similarly, Edward B. Smith declares that "I have seldom seen an English teacher who could bring high school students to an appreciation of Shakespeare” (15). Meanwhile, in an essay titled “To Be or Not to Be (Loved)” for Black Issues in Higher Education, one professor states that it is only "the intellectual contribution of a text drives the book selection process” (Kellman 3). In terms of curriculum, book selections based on historical/intellectual merit would seem to be the problem of the canon. Since canonical literature is traditionally the literature that gets the most focus, it will inevitably be works from that which have contributed the most intellectually.

With a changing world, our discipline, and approaches to it, must necessarily change as well if we are to continue to hold true to the driving idea behind the humanities: to explore what it means to be human. This means that current curriculums will have to start reflecting an increasingly globalized world. In contrast to the conception of the canon as an internal dialectic, Annete Kolodny offers a different kind of canon- 
one that "declares that literary change is dependent upon societal development and therefore determined by upheavals in the social and economic organization of the culture at large” (504). While this addresses a change in the ideological foundation of the canon, it does nothing to suggest how English departments might move forward in making this kind of change happen. What I would suggest is not that we rid ourselves of Shakespeare-it is not his literary history which is at question, but his privileged status as representative of the English degree- - but rather elevate other writers and areas of study to the same level of privilege. In the English department at Florida International University, we have a Renaissance requirement according to which students can choose to take a single-author class on Shakespeare, Milton, or Spenser. There is also a Multicultural requirement, which can mean taking one of a variety of classes ranging from African American literature to Latin American literature, and literature of Exile. The problem here arises in that while a student can go through the English program and never study Shakespeare as a single author, it is also possible for them to receive their Bachelors in Arts without ever studying an entire genre of literature from a variety of marginalized communities. What I would propose is a reworking of the English Literature curriculum to include requirements for African American literature, Latin American literature, Native American literature, etc. While this would require a reworking of the entire degree requirements, the benefits could have longstanding effects towards increasing enrollment in the humanities as well as placing English at the forefront of a charge towards the changing face of academia. Ultimately, the humanities should strive towards a society that is not only better educated, but more compassionate and inclusive. 


\section{CONCLUSION}

So then why the rats? What is important about the plague rats? Inevitably what the inclusion of these small rodents confirm is that students from outside the white community have a hard time relating to Shakespeare’s London, let alone his work. The rats are funny and unexpected: we know rats, we know we do not like them, and we know that they drag pizzas across New York subway stations. What is not known is the degree of separation between the work of Shakespeare, other canonical writers, and the students who are required to develop new and innovative ways to write about something that does not reinforce the sense that the university values their backgrounds and lived experiences. With my experience digitally recreating Bankside and The Globe, I had to make design choices so that students could experience a virtual reality that meant something to them. What I did not count on was the way in which this would be so difficult. Digital production within the humanities would seem to suggest that there are whole new areas of inquiry and analysis that can come about through virtual reality work. I am both excited and nervous to see what will arise, but if digital work continues with the canon, it is my belief that we will see a movement away from the myth of its universality. 


\section{Bibliography}

American Academy of Arts and Sciences. "Bachleors Degrees in the Humanities." Bachelor's Degrees in the Humanities. American Academy of Arts and Sciences, Jan. 2015. Web. 12 Feb. 2016.

Benjamin, Walter, and Hannah Arendt. Illuminations. New York: Schocken, 1986. Print.

Bogost, Ian. Persuasive Games: The Expressive Power of Videogames. Cambridge, MA: MIT, 2007. Print.

Brown, Bryan A., J. Bryan Henderson, Salina Gray, Brian Donovan, Shayna Sullivan, Alexis Patterson, and William Waggstaff. "From Description to Explanation: An Empirical Exploration of the African-American Pipeline Problem in STEM." Journal of Research in Science Teaching J Res Sci Teach 53.1 (2015): 146-77. Web.

Derrida, Jacques, and Eric Prenowitz. Archive Fever: A Freudian Impression. Chicago, Ill.: U of Chicago, 2004. Print.

Ditmore, Melissa Hope. Encyclopedia of Prostitution and Sex Work. Westport, CT: Greenwood, 2006. Print.

Everett, Anna. Digital Diaspora: A Race for Cyberspace. Albany: SUNY, 2009. Print.

Gurr, Andrew. Playgoing in Shakespeare's London. Cambridge: Cambridge UP, 1987. Print.

Hansen, Mark B. N. Bodies in Code: Interfaces with Digital Media. New York: Routledge, 2006. Print.

Hegel, Georg Wilhelm Friedrich, and J. Sibree. The Philosophy of History. New York: Dover Publications, 1956. Print.

Janmohamed, Abdul R. "The Economy of Manichean Allegory: The Function of Racial Difference in Colonialist Literature." Critical Inquiry 12.1 (1985): 59-87. Web.

Kearney, Richard. Modern Movements in European Philosophy. Manchester: Manchester UP, 1994. Print.

Kellman, Sophia N. "TO BE or NOT TO BE (LOVED)." Black Issues in Higher Education 18.7 (2001): 29-31. Web.

Klinkenborg, Verlyn. "The decline and fall of the English major." New York Times 22 (2013): 268. 
Kolodny, Anette. "Annette Kolodny." Critical Theory since 1965. Ed. Hazard Adams and Leroy Searle. Tallahassee: Florida State UP, 1986. 497-512. Print.

Loomba, Ania. Colonialism/postcolonialism. London: Routledge, 2005. Print.

Lorde, Audre. Sister Outsider: Essays and Speeches. Berkeley, CA: Crossing, 2007. Print.

Mack, Sammy. "Shakespeare Visits Miami With Rare Book And Virtual Reality." Shakespeare Visits Miami With Rare Book And Virtual Reality. The Miami Herald, 9 Feb. 216. Web. 12 Feb. 2016.

Martin-Smith, Alistair, Anette Hayton, and Maya Ishiura. "Emancipating Shakespeare: Cultural Transmission or Cultural Transformation." Caribbean Quarterly 2nd ser. 53.1 (2007): 150-59. Web.

Mechdyne. "Modeling \& Simulation." Mechdyne Corporation. Blue Compass Interactive, 2016. Web. 12 Feb. 2016.

Miami-Dade County Public Schools, comp. Statistical Highlights 2014-2015. Publication. Miami-Dade County Public Schools, Apr. 2015. Web. 30 Mar. 2016.

Nancy, Jean-Luc. Retreating the Political. Trans. Philippe Lacoue-Labarthe. Ed. Simon Sparks. London: Routledge, 1997. Print.

Russell, Heather. Legba's Crossing: Narratology in the African Atlantic. Athens: U of Georgia, 2009. Print.

Smith, Edward B. "Fresh Fish or More Shakespeare?" American Secondary Education 21.3 (1993): 15-18. JSTOR. Web. 12 Feb. 2016.

Trouillot, Michel-Rolph. Silencing the Past: Power and the Production of History. Boston, MA: Beacon, 1995. Print.

Walser, Randall. "Spacemakers \& the Art of the Cyberspace Playhouse.” Mondo 20002 (summer 1990): 60-61. 